DOI: $10.17516 / 1997-1370-0817$

УДК $378+37.04$

\title{
Assessment of the Development Level of Future Primary School Teachers' Special Competences at the University
}

\author{
Gulsum S. Ayapbergenova, Arna Zh. Aplashova, \\ Nagima A. Bissembayeva, Nazymgul S. Assenova \\ and Solpan Zh. Alimova* \\ Pavlodar Pedagogical University \\ Pavlodar, Kazakhstan
}

Received 19.07.2021, received in revised form 24.07.2021, accepted 10.08.2021

\begin{abstract}
The authors investigate the leading problem of the formation of future primary school teachers' special competences in the process of professional training. This study was conducted to identify the initial level of special competences the future primary school teachers of Karaganda Buketov University have. The results of the study have shown that the students demonstrate a generally low level of formation of special competences, which can significantly complicate the process of improving the quality of training a future primary school teacher of a new type for the pedagogical activity in the 21 st century. The study has revealed that the first-year students with low academic performance and lack of knowledge, skills and abilities necessary for future pedagogical activity have a low level of formation of the components of future primary school teachers' special competences, which confirms our hypothesis. The article argues that the low level of special competencies of students cannot contribute to the successful formation of the professional competence of graduates of higher educational institutions.
\end{abstract}

Keywords: special competence, future primary school teachers, assessment, professional training, modernization of education.

Research area: pedagogy.

Citation: Ayapbergenova, G., Aplashova, A., Bissembayeva, N., Assenova, N. Alimova, S. (2021). Aassessment of the development level of future primary school teachers' special competences at the Unıversity. J. Sib. Fed. Univ. Humanit. soc. sci., 14(9), 1266-1276. DOI: 10.17516/1997-1370-0817

(C) Siberian Federal University. All rights reserved

* Corresponding author E-mail address: alimova@mail.ru

ORCID: 0000-0002-4952-3289 (Ayapbergenova); 0000-0002-5736-6199 (Aplashova); 0000-0002-4369-3308 (Bissembayeva); 0000-0002-6027-0809 (Assenova) 0000-0003-4254-1932 (Alimova) 


\title{
Оценка уровня развития специальных компетенций будущих педагогов начальной школы в вузе
}

\author{
Г.С. Аяпбергенова, А.Ж. Аплашова, \\ Н.А. Бисембаева, Н.С.Асенова, Ш.Ж.Алимова \\ Павлодарский педагогический университет \\ Казахстан, Павлодар
}

\begin{abstract}
Аннотация. Авторы поднимают здесь ведущую проблему формирования специальных компетенций у будущих педагогов начальной школы в процессе профессиональной подготовки. Исследование было проведено для выявления базового уровня специальных компетенций студентов Карагандинского университета имени академика Е. Букетова. Результаты продемонстрировали в целом низкий уровень сформированности таких компетенций, что может существенно усложнить процесс повышения качества подготовки будущего педагога начальной школы нового типа в XXI веке. При этом первокурсники со слабой успеваемостью и отсутствием необходимых для предполагаемой педагогической деятельности знаний, умений и навыков имеют и низкий уровень сформированности компонентов специальных компетенций, что подтверждает нашу гипотезу. Вместе с тем недостаточный уровень специальных компетенций студентов не может способствовать успешному формированию профессиональной компетентности выпускников высших учебных заведений.
\end{abstract}

Ключевые слова: специальная компетенция, будущие учителя начальной школы, оценка, профессиональная подготовка, модернизация образования.

Научная специальность: 13.00.00 - педагогические науки.

\section{Introduction}

Nowadays the Kazakhstani education system places new requirements on the level of professional competence of graduates of higher educational institutions. However, what level of professional competence of graduates of higher educational institutions can we talk about, if originally Kazakhstani pedagogical higher educational institutions mainly train students with rather low academic performance, who, in their turn, having completed their studies at the university, go to work in secondary schools and train weak students as well. Then, students of a huge number of specialties obtain secondrate education and are not adjusted to teaching after graduation. The reasons for the low level of novice teachers' competence include both the quality of the educational process in universities and the little appeal of the profession itself. At the present days the latter is a big problem, which devalues the whole education system in the country.

The research on the problem of developing the special competence of the future teacher presents that it is to be solved in the succeeding directions: the use of varied means of information, game and developmental technologies in the formation of a future teacher's professional competence; fullfillment of the industrial (pedagogical) practice potential in the development of a future teacher's special competence. Furthermore, recently there have been a number of studies aimed at the formation of different types of competences in the process of professional training of psychological, psychological and pedagogical, information and professional, communicative, autopedagogic, social and psychological competences.

The versatility of our research on the problem of developing the special competence of 
a future primary school teacher has led to the urge to appply various approaches to the study of the core of this phenomenon - systemic (synthesis of versatile knowledge about the object into a single whole), personality-oriented (orientation to the person as a goal, subject and result of the effectiveness of the educational process), and competence-based (focus of professional training on the formation of the basic components of special competence, reflecting the features of a primary school teacher's activity).

Grossman, Hammerness, McDonald, and Sleeter state that challenges in pointing out the mechanisms of formation of primary school teachers' professional competences are due to their intricacy, synthesis, as well as the presence of a personal component (Borko, 2004; Guskey, 2002). Methods of improving the teacher's professional skills and the formation of their personal qualities are distinguished (Jacobs et al., 2014; Armour et al., 2012).

Special professional competences are competences (i. e. readiness and eagerness), needed for the activity of a primary school teacher (Qualters, 2001; Kahn et al., 2005; Desimone, 2009; Neustroeva et al., 2018; Gluzman et al., 2018).

The development of special competences has also been examined by many researchers (Halász, 2011; Hopfenbeck, 2018; Kot et al., 2020).

In his research Ertmer states that special competence is of peculiar importance because of the fact that the education system is currently undergoing substancial contemporary transformations (Ertmer, 2003).

Ertmer, Ottenbreit-Leftwich, Friedrich, Trainin and others identify the consecutive elements in the structure of the teacher's professional competence: the condition of readiness and the desire for activity. These are the motivational and personal fundamentals of the activity, which include motivation, knowledge, skills, and experience (Ertmer et al., 2010).

In this case, attention is concentrated on the development of abilities, knowledge, skills, motives, views, beliefs and values vital for a prosperous professional activity (Desimone et al., 2014).
The motives correlating with the interest in the chosen profession become a resource and an imperative for the further professional development. Besides, these motives should be permanent and joined with the sufficient knowledge in the chosen profession (Rocío et al., 2015).

The process of development of the special competence will be successful, if one has determined a set of professional competences needed by a future primary school teacher for solving professional tasks (Valente et al., 2020).

It is crucial that the future teacher possesses professional knowledge and skills to involve students in the system of public relations, the development of their value attitude to knowledge, etc (Misbah et al., 2015; van Dinther et al., 2014).

Neustroeva, Pavlova, Borisova, Okoneshnikova, and Sidorova have found out that a special competence is a set of special knowledge, skills, and personal qualities that meet the professional requirements (Neustroeva et al., 2018).

Special competence is a professional stance, value interests, and professional autonomy; special competence is knowledge, skills, personal experience, skills (Grigoryeva et al., 2019; Drach Slobodianiuk, 2020; Ertmer, 2003; Oliver et al., 2020).

The special competence of the future primary school teacher is defined both as an array of decisive psychological and pedagogical, subject and methodological knowledge and skills, and as a readiness for their practical appliance (Brockmann et al., 2008).

The accomplishment of the signtificant importance of the teaching motive for academic efficiency has led to the justification of the principle of motivational support of the educational process (Eccles et al., 2002).

Nowadays there are many systems for evaluating the level of a future primary school teacher's professional qualifications. At the same time, it should be noted that many of them are aimed at analyzing the formation of only the knowledge and activity components of professional competences (O'Neill et al., 2011; Wahyuddin, 2016; Emmer et al., 1991). 
The future specialist's competences in their particular composition include, in our opinion, general competences (for graduates of all universities) and special (for a definite field of work). In each group respectively, it is also possible to identify the socio-psychological competence and the professional competence.

The phenomenon of a primary school teacher's professional activity lies in the integrity of theoretical knowledge and practical readiness for a set of primary school subjects; personal functions and experience of dealing with younger students; the readiness to construct cognitive needs, the ability to provide the unity of the cognitive, emotional and behavioral components of the student's personality. We suggest the following structural components of special competence: motivational, activity and reflexive competences.

A significant part of teachers meet great difficulties in adapting to rapidly changing social, economic, and professional conditions, and then lack of professional competence can lead to serious social and psychological problems of a person (Campbell, 2017).

We are highly interested in the works on the formation of the special competence of the future primary school teachers. Nevertheless, the available sources devoted to our field of interest represent the specifics of the development of the future primary school teachers' special competence quite poorly.

Indeed, there is no universal approach to the development of special competencies in Kazakhstan yet. It is necessary to take into account the fact that Kazakhstani pedagogical higher educational institutions enlist students with low academic performance, who, in their turn, having graduated, start working in schools and teach identically weak students. This has led us to formulating the research problem: What is the initial level of professional competences (in particular, the block of special competences) of future primary school teachers in the process of professional training?

The aim of the research is to detect the initial level of the formation of future primary school teachers' special competence components.

\section{Methodology \\ Participants}

300 students of three educational institutions in the central Kazakhstani region were requested to take part in the research. A total of 240 of them are future primary school teachers who have expressed their willingness to voluntarily participate in the study. Only students with low scores on the entrance exams $(n=121)$ were selected for the given study.

Among the 121 participants aged 17-22 $44.6 \%$ were female and $25.4 \%$ were male, and their average age was 19.4 years. All students have the Kazakhstani citizenship and study at a state university. The testing was conducted by trained researchers and lasted about 2.5 hours.

\section{Measures}

To determine the degree of the formation of special competences the following methods have been used:

1. The diagnosis of the formation of the motivational component was conducted using a questionnaire due to the methods of K. Zamfir under A. Rean's modification (Gubina, 2020).

2. The initial level of the cognitive component formation was determined by testing, including the monitoring of the participants' progress in natural science disciplines).

3. Diagnostics of the cognitive component formation was carried out by experts. These were teacher methodologists of the Department of Pedagogy and Primary Education.

4. The formation of the reflexive component was determined using reflection maps, self-assessment, and questionnaire.

\section{Procedure}

All participants of the study were absolutely aware of the core of the study and were guaranteed the confidentiality of all obtained data before beginning the study. The study was carried out on the recommendation and approval of the Ethics Committee of Karaganda Buketov University (Karaganda, Kazakhstan). All procedures were organized with the permission of the university administration, the teaching staff, and the participants. 


\section{Results}

Table 1 shows that future primary school teachers are grouped according to the level of formation of the first indicator in the control and experimental groups.

The results demonstrate that the formation of the motivational component in the control and experimental groups is at a low level from $87,5 \%$ to $96,29 \%$, from $3,70 \%$ to $12,5 \%$ at a medium level, and the high level is not detected.

The table below reveals the data on the formation of the cognitive component of students' special competences.

As seen in Table 2, future primary school teachers' cognitive component formation in the control and experimental groups is at a low level from $80,00 \%$ to $90,62 \%$, from $9,37 \%$ to $13,33 \%$ at a medium level, and the high level is not revealed.
The data on the formation of the activity component of the special competences is presented in Table 3.

The results shown in Table 3 prove that the future primary school teachers have a low level of the activity component formation in the control and experimental groups from 71,87\% to $88,88 \%$, from $11,11 \%$ to $28,12 \%$ at middle level, and there is no high level.

Table 4 includes the data on the formation of the reflective component of the special competences.

The results of the analysis shown in Table 4 display that the formation of the reflexive component both in the control and experimental groups of future primary school teachers is at a low level from $78,13 \%$ to $85,18 \%$, from $14,81 \%$ to $20,00 \%$ at a medium level, and high level is absent.

Table 1. Students' data on the levels of formation of the motivational component of the special competences

\begin{tabular}{|c|c|c|c|c|c|c|c|}
\hline \multirow{2}{*}{ Groups } & \multirow{2}{*}{$\begin{array}{c}\text { Number } \\
\text { of students }\end{array}$} & \multicolumn{2}{|c|}{ Low level } & \multicolumn{2}{c|}{ Medium level } & \multicolumn{2}{c|}{ High level } \\
\cline { 3 - 8 } & & number & $\%$ & number & $\%$ & number & $\%$ \\
\hline CG & 30 & 27 & 90,00 & 3 & 10,00 & 0 & 0.00 \\
\hline EG-1 & 27 & 26 & 96,29 & 1 & 3,70 & 0 & 0.00 \\
\hline EG-2 & 28 & 26 & 92,8 & 2 & 7,14 & 0 & 0.00 \\
\hline EG-3 & 32 & 28 & 87,5 & 4 & 12,5 & 0 & 0.00 \\
\hline
\end{tabular}

Table 2. The data on the formation of the cognitive component of students' special competences

\begin{tabular}{|c|c|c|c|c|c|c|c|}
\hline \multirow{2}{*}{ Groups } & \multirow{2}{*}{$\begin{array}{c}\text { Number } \\
\text { of students }\end{array}$} & \multicolumn{2}{|c|}{ Low level } & \multicolumn{2}{c|}{ Medium level } & \multicolumn{2}{c|}{ High level } \\
\cline { 3 - 8 } & & number & $\%$ & number & $\%$ & number & $\%$ \\
\hline CG & 30 & 26 & 86,66 & 4 & 13,33 & 0 & 0.00 \\
\hline EG-1 & 27 & 24 & 80,00 & 3 & 11,11 & 0 & 0.00 \\
\hline EG-2 & 28 & 25 & 83,33 & 3 & 10,00 & 0 & 0.00 \\
\hline EG-3 & 32 & 29 & 90,62 & 3 & 9,37 & 0 & 0.00 \\
\hline
\end{tabular}

Table 3. The data on the formation of the activity component of the special competences

\begin{tabular}{|c|c|c|c|c|c|c|c|}
\hline \multirow{2}{*}{ Groups } & \multirow{2}{*}{$\begin{array}{c}\text { Number } \\
\text { of students }\end{array}$} & \multicolumn{2}{|c|}{ Low level } & \multicolumn{2}{c|}{ Medium level } & \multicolumn{2}{c|}{ High level } \\
\cline { 3 - 8 } & & number & $\%$ & number & $\%$ & number & $\%$ \\
\hline CG & 30 & 26 & 86,66 & 4 & 12,5 & 0 & 0.00 \\
\hline EG-1 & 27 & 24 & 88,88 & 3 & 11,11 & 0 & 0.00 \\
\hline EG-2 & 28 & 23 & 85,18 & 5 & 17,85 & 0 & 0.00 \\
\hline EG-3 & 32 & 23 & 71,87 & 9 & 28,12 & 0 & 0.00 \\
\hline
\end{tabular}


Table 4. The data on the formation of the reflective component of the special competences

\begin{tabular}{|c|c|c|c|c|c|c|c|}
\hline \multirow{2}{*}{ Groups } & \multirow{2}{*}{$\begin{array}{c}\text { Number } \\
\text { of Students }\end{array}$} & \multicolumn{2}{|c|}{ Low level } & \multicolumn{2}{c|}{ Medium level } & \multicolumn{2}{c|}{ High level } \\
\cline { 3 - 8 } & & number & $\%$ & number & $\%$ & number & $\%$ \\
\hline CG & 30 & 24 & 80,00 & 6 & 20,00 & 0 & 0.00 \\
\hline EG-1 & 27 & 23 & 85,18 & 4 & 14,81 & 0 & 0.00 \\
\hline EG-2 & 28 & 22 & 78,57 & 6 & 21,42 & 0 & 0.00 \\
\hline EG-3 & 32 & 25 & 78,13 & 5 & 15,62 & 0 & 0.00 \\
\hline
\end{tabular}

Table 5. The level of readiness of future primary school teachers for the formation of special competences

\begin{tabular}{|c|c|c|c|c|}
\hline \multirow{2}{*}{ Groups } & \multirow{2}{*}{ Number of students } & \multicolumn{3}{|c|}{ Levels } \\
\cline { 4 - 5 } & & Low level & Medium level & High level \\
\cline { 5 - 5 } & 30 & $\%$ & $\%$ & $\%$ \\
\hline CG & 27 & 85,83 & 13,95 & 0.00 \\
\hline EG-1 & 28 & 87,58 & 10,18 & 0.00 \\
\hline EG-2 & 32 & 82,03 & 14,10 & 0.00 \\
\hline EG-3 & & 16,40 & 0.00 \\
\hline
\end{tabular}

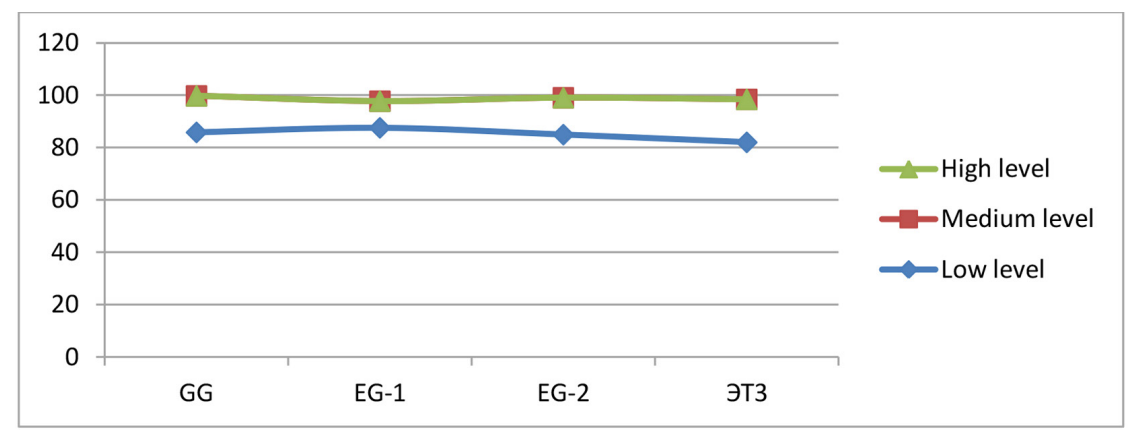

Fig. 1. Indicators of the level of future primary school teachers' readiness to form special competences

We have also studied the readiness of future primary school teachers for the formation of special competences (See Table 5).

The results of the analysis on the distribution of the levels of future teachers' readiness for the formation of special competencies, shown in Table 5, are seen that the level of readiness of future primary school teachers in the control and experimental groups is at a low level from $82,03 \%$ to $87,58 \%$, from $10,18 \%$ to $19,40 \%$ at a medium level, and there is no high level of readiness.

As shown in Figure 1, the lowest level of readiness of future primary school teachers is $87,58 \%$ in the first experimental group,
$84,97 \%$ in the second group, $82,033 \%$ in the third group, and $85,83 \%$ in the control group. The average level in the experimental group is the following: EG 1-10,18 \%, EG 2-14,10\%, EG $16,40 \%$. In the control group it is $13,95 \%$. The high level was not discovered both in the experimental group and the control group.

\section{Discussion and conclusıon}

In our research we strove to study the initial level of formation of the components of the special competences the bachelors of pedagogical education in the field of «Primary Education» demonstrate. We made an attempt to overcome the limitations of previ- 
ous research conducted in this area by considering the formation of the components of future primary school teachers' special competences.

The results of the study let us know that first-year students with low academic performance and lack of knowledge and skills needed for future teaching activities have a low level of formation of the components of special competences of future primary school teachers, which confirms our hypothesis.

The study claims that the student' low level of special competences can not successfully contribute to the successful formation of professional competence of graduates of higher educational institutions. Consequently, the educational programs of higher education institutions have a poor focus on the formation of professional competences as integral entities. These involve knowledge, skills, and abilities, but they are deficient in psychological attitudes, personal qualities, as well as professional experience.

We believe that the low level of development of future teachers' special competences is characterized by:

- insufficient knowledge of the basics of primary education pedagogy;

- ignoring the age-related psychophysiological features of a primary schoolchild, the laws of development and the personality formation, knowledge of the basics of mathematics, natural science and other subjects, inability to operate with them;

- poor knowledge of methods and techniques of diagnostics of a primary schoolchild (difficulty in analyzing the received data);

- absence of pedagogical skills, intuitive nature of solving professional problems (not relying on the existing unsystematic knowledge often leads to making mistakes);

- inability to independently conduct empirical and theoretical research;

- lack of substantial motives and interests for teaching activities with a positive attitude to it, the aspiration for professional enhancement and development;

- the presence of deficient self-esteem and mental preparedness for conducting professional and pedagogical activities;
- insufficient knowledge of future primary school teachers.

The preceeding studies have supported the results of this study, too. This finding is consistent with the research by Darling-Hammond, Hyler, \& Gardner (2017).

What's more, practice-oriented training courses are not justified in the sufficient degree or are not allocated. This may be due to the fact that the stucture of the professional competences of a bachelor, defined in the state standard for «Pedagogical education», is generalized. The designation of professional competences is assumed at the level of the main educational program of the university, but the analysis of the programs of various pedagogical universities has made us suggest that the special competences of the bachelor education in the context of modernization of the Kazakhstani education content have not been reflected yet. Meanwhile, the structure of such competences, as well as the technology of their formation, due to their over-subject nature, has its own specifics.

The question of teacher professional training is studied from different angles, which provides various approaches to its solution. For example, Little, Guskey, Kennedy have alleged that activity-based and personality-oriented approaches allow to consider students as subjects of education, and purposefully not only give knowledge, develop skills and abilities, but also ways of professional activity (Little, 1993; Guskey, 2002; Kennedy, 2005).

We suggest that the development of the special competence of the future primary school teacher at university is a interminable process of continuous inclusion of students into educational and professional activities basing on the systematic, personality-oriented and competence-based approaches. Therefore, different studies reflect different aspects of the research object and, therefore, become most effective when combined with other approaches (Blase \& Blase, 2000; Slavin, 2008).

The results of our research state that when preparing a future teacher in the course of a university educational process, it is necessary to take into consideration the following factors that influence the development of a future primary school teacher's special competences: 
- socio-pedagogical factors: the status of a primary school teacher in the contemporary society; the requirements to a primary school teacher put by the society; the opportunities for professional training;

- personal growth; the educational environment of the university; the forms and methods of organizing the educational process and pedagogical practice;

- psychological, pedagogical and psychophysiological prerequisites of pedagogical activity;

- motives for choosing a profession;

- bias, interests, value orientations of a student;

- the subject of knowledge and skills; the ability to set pedagogical tasks and organize pedagogical situations;

- skills of pedagogical self-analysis and self-diagnosis;

- changing the level of students' awareness of the need to master a special competence;

- creating a developing personalityoriented educational environment that promotes the formation of professional activity motives, experience acquisition in the continuous self-education;

- persistent formation of future primary school teacher's personal functions (motiva- tional, activity, reflexive) (Integrating Engineering Education and Humanities for Global Intercultural Perspectives, 2020).

The contribution of the research to the study of the future primary school teacher's special competences is that the theoretical concepts of the core and structure of the bachelor's special competences («Primary education» profile) in the aggregate of all their components are clarified, a set of special competences is elaborated and presented as a result of future primary school teachers' education, clarifying and supplementing professional competences.

We suggest that the research should gain further prospects. It is advisable to find out the nature of the relationship between the conditions for the formation of various types of competences from the composition of the professional competence of primary school teachers and from these positions to advance the learning process. Moreover, it is possible to extend the suggested model to other levels of education (secondary and vocational education) in order to train future teachers for the implementation of activities in the context of realization of the requirements of the state standard (taking into account their specifics).

\section{References}

Ayapbergenova, G. S., Nurgaliyeva, S. A., Bissembaeva, N. A., Kabakova, M. P., \& Koyshibaev, M. N. (2020). Development of project skills of future primary school teachers at university, In Science for Education Today, 10 (6), 7-26. DOI: http://dx.doi.org/10.15293/2658-6762.2006.01 Available at: http://sciforedu. ru/system/files/articles/pdf/07_ayapbergenova_6-20z.pdf?

Armour, K.M., Makopoulou, K. (2012). Great expectations: Teacher learning in a national professional development programme, In Teaching and Teacher Education: An International Journal of Research and Studies, 28(3), 336-346.

Blase, J., Blase, J. (2000). Effective instructional leadership: Teachers' perspectives on how principals promote teaching and learning in schools, In Journal of educational administration, 38 (2), 130-141.DOI: $10.1108 / 09578230010320082$

Borko, H. (2004). Professional development and teacher learning: Mapping the terrain, In Educational Researcher, 33(8), 3-15. DOI: 10.3102/0013189X033008003

Brockmann, M., Clarke L., Méhaut P., \&Winch, C. (2008). Competence-based vocational education and training (VET): The cases of England and France in a European perspective, In Vocations and Learning, 1(6), 227-244. DOI: 10.1007/s12186-008-9013-2.

Campbell, C. (2017). Developing teachers' professional learning: Canadian evidence and experiences in a world of educational improvement, In Canadian Journal of Education/Revue Canadienne De l'éducation, 40(2), 1-33. 
Darling-Hammond, L., Hyler, M. E., \& Gardner, M. (2017). Effective Teacher Professional Development. Palo Alto, CA: Learning Policy Institute. Available at: https://learningpolicyinstitute.org/

Desimone, L. M. (2009). Improving impact studies of teachers' professional development: Toward better conceptualizations and measures, In Educational Researcher, 38(3), 181-199. DOI: 10.3102/0013189X08331140

Desimone, L., Stuckey, D. (2014). Sustaining professional development. In. L. Martin, S. Kragler, D. Quatroche, \& K. Bauserman (Eds.), Handbook of professional development in Education: Successful Models and Practices, Prek, 467-482. New York, NY: Guilford Publications.

Dianne, M., Garyantes \& Murphy, P.(2019). The cultural competence of health journalists: Obesity coverage in four urban news organizations, In Health Communication, 34 (2),191-200. DOI:10.1080/10410 236.2017.1399507

Drach, I., Slobodianiuk, O. (2020). Building a culture of academic integrity in the student environment case of Vinnytsia National Technical University (Ukraine), In Creative Education,11(8). DOI:10.4236/ ce. 2020.118105

Eccles, J. S., Wigfield, A. (2002). Motivational beliefs, values, and goals, In Annu. Rev. Psychol. 53, 109-132. DOI:10.1146/annurev.ps53.100901.135153

Emmer, E. T., Hickman, J. (1991). Teacher efficacy in classroom management and discipline, In Educational and Psychological Measurement, 51, 755-765. DOI:10.1177/0013164491513027

Ertmer, P. (2003). Transforming teacher education: visions and strategies, In Educational Technology Research and Development, 51(1), 124-128. DOI:10.1007/BF02504522

Ertmer, P. A., Ottenbreit-Leftwich, A. T. (2010). Teacher technology change: How knowledge, confidence, beliefs, and culture intersect, In Journal of Research on Technology in Education, 42(3), 255-284. DOI:10.1080/15391523.2010.10782551

Espinar Redondo, Rocío, Ortega Martín, \& José Luis. (2015). Motivation: The road to successful learning, In Profile Issues in Teachers' Professional Development, 17(2), 125-136. DOI:10.15446/profile. $\mathrm{v} 17 \mathrm{n} 2.50563$

Friedrich, L., \& Trainin, G. (2016). Paving the way for new literacies integration in elementary teacher education, In Creative Education, 7, 1456-1474. DOI: 10.4236/ce.2016.710151

Garet, M. S., Porter, A. C., Desimone, L., Birman, B. F., \& Yoon, K. S. (2001). What makes professional development effective? Results from a national sample of teachers, In American Educational Research Journal, 38(4), 915-945. DOI:10.3102/00028312038004915

Gómez-Rodríguez, L. F. (2018). EFL learners' intercultural competence development through international news, In GIST - Education and Learning Research Journal, 16, 185-208. DOI: 10.26817/16925777.431

Grossman, P., Hammerness, K., \& McDonald, M. (2009). Redefining teaching, reimagining teacher education, In Teachers and Teaching: Theory and Practice, 15(2), 273-289. DOI:10.1080/13540600902875340

Gluzman, N. A., Sibgatullina, T. V., Galushkin, A. A., \& Sharonov, I. A. (2018). Forming the basics of future mathematics teachers' professionalism by means of multimedia technologies, In Eurasia Journal of Mathematics, Science and Technology Education, 14(5), 1621-1633. https://doi.org/10.29333/ejmste/85034

Grigoryeva, S. G., Grigoryeva, L. G., \& Russkov, S. P. (2019).Cause and effect relations of the competences forming process for innovative activity of future primary school teachers. In: Valeeva $R(E d)$ VInternational Forum on Teacher Education, Kazan Federal University, Russia. 29-31 May 2019. ARPHA Proceedings 1: 223-231. Available at: https://doi.org/10.3897/ap.1.e0207

Gubina, L. V. (2020). Comparative analysis of the motivation of students' professional choice in different areas of training, In Pedagogical Education in Russia. 3, 73-80. DOI 10.26170/po20-03-08.

Guskey, T. R. (2002). Professional development and teacher change, In Teachers and teaching, 8(3), 381-391. DOI:10.1080/135406002100000512

Halász G, Michel, A. (2011). Key competences in Europe: interpretation, policy formulation and implementation, In European Journal of Education, 46 (3), 289-306. DOI: 10.1111/j.1465-3435.2011.01491.x

Integrating engineering education and humanities for global intercultural perspectives (2020). Springer, Chamhttps://doi.org/10.1007/978-3-030-47415-7 Available at: https://link.springer.com/ 
Hiçyorulmaz, E., Akdoğan, H. (2017). The profession of the future in the field of accountıng: accountıng engineerıng. International Conference on New Horizons in Education Conference (INTE) - ITICAM-\$5DEC, Berlin-GERMANY, In Proceedings Book, 3, 859-863. Available at: https://baixardoc.com/

Jacobs, J., Yendol-Hoppey, D. (2014). Using action research to target and generate professional learning. In L. E. Martin, S. Kragler, D. J. Quatroche, \& K. L. Bauserman (Eds.). Handbook of professional development in education: Successful models and practices, preK-12, 304-318. New York, NY, Guilford Press.

Kahn, P., O'Rourke, K. (2005). Understanding enquiry-based learning, In Handbook of Enquiry \& Problem Based Learning, 1-12.

Kennedy, A. (2005). Models of continuing professional development: a framework for analysis, In Journal of In-Service Education, 31(2), 235-250, DOI: 10.1080/13674580500200277

Kot, T. A., Zotova, I. V., \& Bogoslova, E. G. (2020). Methodical system of future primary school teachers' research skills development, In SHS Web of Conferences, 87, 00099. doi:10.1051/shsconf/20208700099

Little, J. W. (1993). Teachers' professional development in a climate of educational reform, In Educational Evaluation and Policy Analysis, 15(2), 129-151. DOI: 10.3102/01623737015002129

Marko, M. (2017). Elaboration of the model of formation of readiness of future primary school teachers to the use of learnıng-playıng technologies, In EUREKA: Social and Humanities, (5), 10-16. https://doi. org/10.21303/2504-5571.2017.00406

McGarr, O., Gallchóir, C. Ó (2020). Exploring pre-service teachers' justifications for one-to-one technology use in schools: implications for initial teacher education, In Technology, Pedagogy and Education, 29 (4), 477-490, DOI:10.1080/1475939X.2020.1784261

Misbah, Z., Gulikers, J., Maulana, R., \& Mulder, M. (2015). Teacher interpersonal behaviour and student motivation in competence-based vocational Eeducation: evidence from Indonesia, In Teaching and Teacher Education, 50: 79-89. DOI: 10.1016/j.tate.2015.04.007.

Neustroeva, A., Pavlova, E., Borısova, T., Okoneshnıkova, N., \&Sidorova, E. (2018). The role of pedagogical practice in the employment of bachelors of the University (experience of the Ammosov NorthEastern Federal University-NEFU, Russia), In Revista Espacios, 39(40), 18. http://www.revistaespacios. com/

O’Neill, S. C., Stephensen, J. (2011). Teacher classroom behaviour management preparation in undergraduate primary education in Australia: a web-based investigation, In Australian Journal of Teacher Education, 36, 35-52. DOI: 10.14221/ajte.2011v36n10.3

Professional competency of modern specialist: means of formation, development and improvement: monograph (2018). Warsaw: BMT Eridia Spz o. o., 424. Available at: https://www.ssoar.info/ssoar/handle/ doc

Qualters, D.M. (2001). Do students want to be active? In Journal of Scholarship of Teaching and Learning, 2 (1), 51-60.

Slavin, R. E. (2008). Perspectives on evidence-based research in education -what works? Issues in synthesizing educational program evaluations, In Educational Researcher, 37(1), 5-14. DOI: 10.3102/0013189X08314117

Sleeter, C. (2014). Toward teacher education research that Iinforms policy, In Educational Researcher, 43(3), 146-153. DOI: 10.3102/0013189X14528752

Therese N. Hopfenbeck (2018). Classroom assessment, pedagogy and learning - twenty years after Black and Wiliam 1998, In Assessment in education: Principles, policy\& practice, 25(6), 545-550. DOI: 10.1080/0969594X.2017.1377685

van Dinther, M., Dochy F., Segers M., \& Braeken, J. (2014). Student perceptions of assessment and student self-efficacy in competence-based education, In Educational Studies, 40, 330-351. DOI: 10.1080/03055698.2014.898

Van den Bergh, L., Ros, A., \& Beijaard, D. (2014). Improving teacher feedback during active learning: Effects of a professional development program, In American Educational Research Journal, 51(4), 772-809. DOI: $10.3102 / 0002831214531322$ 
Valente, S., Lourenço, A.A., Alves, P., \& Domínguez-Lara, S. (2020). The role of emotional intelligence capacity for teacher's efficacy and classroom management efficacy. Rev.,, In CES Psico, 13(2), 18-31. DOI: $10.21615 /$ cesp.13.2.2

Wahyuddin, W. (2016). The relationship between of teacher competence, emotional intelligence and teacher performance Madrasah Tsanawiyah at district of SerangBanten, In Higher Education Studies, 6(1), 128-135. DOI: 10.5539/hes. v6n1p128 